\title{
Appetite control and gastrointestinal hormonal behavior (CCK, GLP-1, PYY 1-36) following low doses of a whey protein-rich nutraceutic
}

\author{
Samir Giuseppe Sukkar • Alberto Vaccaro - Giovanni Battista Ravera • \\ Claudia Borrini - Raffaella Gradaschi - Anna Massa Sacchi-Nemours • \\ Renzo Cordera $\cdot$ Gabriella Andraghetti
}

Received: 3 August 2012/Accepted: 4 January 2013/Published online: 5 February 2013

(C) The Author(s) 2013. This article is published with open access at Springerlink.com

\begin{abstract}
Whey proteins represent the most satiating nutrients. In particular, their effects are due to enterohormonal changes (CCK, GLP-1 and PYY 1-36) observed after their exclusive ingestion. Glucomannan has important satiety property due to volume increase following gelification. The aim of the study is the evaluation of subjective rate of hunger and enterohormone concentrations (CCK, GLP-1, PYY 1-36) following oral loading of a mixture containing WP $(8 \mathrm{~g})$ or casein $(8 \mathrm{~g})$ plus glucomannan $(1 \mathrm{~g})\left(\right.$ Colordiet $^{\circledR}$, Inpha DUEMILA Srl Lecco, Italy). The study was conducted as a double-blind crossover with five healthy volunteers (BMI $22-26 \mathrm{~kg} / \mathrm{m}^{2}$ aging $18-65$ years) in acute and a wash-out period of 1 week between the first and the second evaluation. From the analysis of the data, we observe that the load with WP induces a significant decrease in the desire to eat after $90 \mathrm{~min}(P<0.0446)$ when compared with casein. As far as plasma hormones are concerned, there was a significant increase only in GLP-1 at $90 \mathrm{~min}$ after WP $(P<0.00166)$ and $180 \mathrm{~min}$ after casein (T0 vs. T180 $P=0.000129$ ). There is a significant correlation between the increase in GLP-1 and decrease of
\end{abstract}

S. G. Sukkar $(\bowtie) \cdot$ A. Vaccaro · C. Borrini · R. Gradaschi ·

A. Massa Sacchi-Nemours

Clinical Nutrition Unit, IRCCS Azienda Ospedaliera

Universitaria San Martino-IST di Genova, Genova, Italy

e-mail:samir.sukkar@hsanmartino.it

G. B. Ravera

Bio Statistical Institute, Health Science Department (DISSAL), Genoa University, Largo R. Benzi 2, 16122 Genova, Italy

R. Cordera - G. Andraghetti

Department of Endocrinology and Metabolism, IRCCS Azienda

Ospedaliera Universitaria San Martino-IST di Genova,

Genova, Italy desire to eat $(R=-0.93)$. There is a tendency to the increasing of CCK after $90 \mathrm{~min}$, which is not significant $(P=0.091)$. These results could be due to (a) the low number of cases or (b) the low dose of protein used. The present study suggests that a mixture of WP plus glucomannan exerts a decrease in the desire to eat which is correlated to enterohormonal modification (GLP-1 increase) despite the low content of protein $(8 \mathrm{~g})$ and the presence of glucomannan, which could reduce the fast absorption of WP in relation to the net forming during the gelification of the gastric environment.

Keywords Whey protein - Appetite suppressant . GI hormones · CCK · GLP-1 · PYY · Obesity

\section{Introduction}

Recent studies in animals and humans have shown that whey proteins have anorexigenic properties that may be a potential weapon for overweight management. In particular, the anorectic effect of whey proteins (WP) is stronger than that induced by casein, soy proteins and ovalbumin [1].

Whey proteins may reduce caloric intake as a result of various physiological mechanisms. Casein macropeptide (CMP), which is the precursor protein of glyco macropeptide (GMP), is a bioproduct of rennin (chymosin) and a component of whey $(1.2-1.5 \mathrm{~g} / \mathrm{L})$. Over 20 years ago, it was shown that GMP can affect gastrointestinal function through the inhibition of gastric secretion [2], and that this action could be mediated by peptide hormones, such as cholecystokinin (CCK) [3, 4], which is a potent activator of satiety signals. The CCK-like activity of GMP was then confirmed by subsequent studies [5, 6]. Its satiating power 
and weight control action are extremely variable and depend on the physical and chemical properties determining its digestion and absorption with the subsequent release of amino acids. Circulating postprandial amino-acid (AA) levels are amongst the main factors that influence satiety.

There is a wealth of evidence that whey protein effect on satiety and food intake is mediated by the release of satiety-inducing hormones. More than 20 different regulatory peptide hormones are released in the gastrointestinal system. Many of them are involved in regulating food intake and are sensitive to content and composition of intestinal nutrients [9]. A number of them respond after protein consumption and this may account for food intake suppression after milk protein ingestion.

CCK, GLP-1(glucagon-like peptide-1), GIP (Gastric inhibitory polypeptide), PYY (peptide YY), and ghrelin in particular, play a key role. Insulin is involved in the regulation of food intake, both in the short and the long term. Insulin release is stimulated by whey protein ingestion that affects the glycemic response and is closely associated with short-term satiety and decreased food intake [7]. Insulin response has been shown to have a closer correlation with short-term satiety and food intake than do gut hormones.

Anyways, the satiating effects of WP have been proven only when they are administered in a single-dose high load (20-40 g).

This could lead to an protein overload if we consider the recommended dietary allowance (RDA) when the rest of daily food intake is concerned.

Therefore, it could be very interesting to evaluate whether WP lower dosage also determines a similar satiating effect.

The aim of this study was to evaluate the satietyinducing effect and the effect on satiety-associated gut hormones (CCK, GLP-1, PYY 1-36) of an oral administration of low-load whey proteins versus casein $(8 \mathrm{~g} / \mathrm{dose})$.

\section{Materials and methods}

A double-blind crossover study has been conducted employing five healthy volunteer subjects [BMI (body mass index) between 22 and $26 \mathrm{~kg} / \mathrm{mq}$, aged 25-55 years].

In acute, five samples were performed for the first and the second arm of the study with 1-week washout between the two doses.

Patients excluded from the study were those with the following contraindications:

- eating disorders, particularly binge eating disorder (BED), bulimia;

- known or suspected pregnancy;
- depression and/or obsessive-compulsive disorder treated with serotoninergic drugs;

- intake of appetite suppressor drugs;

- inhibiting pancreatic lipase;

- renal failure.

After informed consent has been obtained, each subject underwent the following baseline evaluations:

1. anamnesis and physical examination;

2. anthropometric measures: body weight with calculation of BMI and waist circumference, and

3. assessment of average daily calorie intake by food diary

The study was conducted after an overnight fast and the samples were carried out as follows:

1. The satiating capacity was evaluated by means of Haber's scale, an analog visual scale from -10 (representing extreme hunger: painfully hungry) to +10 (representing extreme satiety: full to nausea) [8]. In particular, the subjects describe the level of agreement with respect to hunger or satiety by pointing to an appropriate place along the graduated visual scale. Assessment of tolerability (adverse events monitoring and reference), which has been transformed in a scale from 1 to 20 for an easy report.

2. Detection of side effects.

3. Five samples were made for each study arm (T0: $0^{\prime}$; T1: 15'; T2: 30'; T3: 90'; T4: 180').

4. CCK, GLP-1 and PYY were assayed in duplicate using radioimmunoassay (RIA kit-Phoenix Pharmaceuticals, Inc. (Burlingame, California, USA), according to the instructions provided.

The procedure contemplates:

Plasma collection the blood was collected into tubes containing EDTA (Greiner VACUETTE ${ }^{\circledR}$ K3E K3EDTA, $4 \mathrm{~mL}$, lavender/black, $13 \times 75 \mathrm{~mm}$ ), ridged and stirred gently to prevent coagulation. Then it was transferred into tubes containing aprotinin $(0.6 \mathrm{TIU} / \mathrm{mL}$ of blood), stirred gently several times to inhibit the activity of proteinase and centrifuged at $1,600 \times g$ for $15 \mathrm{~min}$ at $4{ }^{\circ} \mathrm{C}$. The plasma was stored at $-70{ }^{\circ} \mathrm{C}$.

Plasma extraction the plasma was acidified and centrifuged at $10,000 \times g$ for $20 \mathrm{~min}$ at $4{ }^{\circ} \mathrm{C}$ Then it was loaded onto columns containing $200 \mathrm{mg}$ of Sep Column C18, equilibrated with Buffer B (Buffer B: $60 \%$ acetonitrile in $1 \%$ TFA) and A [Buffer A: $1 \%$ trifluoroacetic (TFA)]. (Phoenix Pharmaceuticals).

The eluate was collected in tubes of polystyrene, concentrated, lyophilized and then reconstituted with RIA buffer. 


\section{Product features}

The composition of the product (containing whey proteins) (Colordiet $^{\circledR}$, INPHA DUEMILA S.r.l., via Elettrochimica n.37, Lecco, Italy) was:

- proteins of the whey concentrate $80 \% 10,000.0 \mathrm{mg}$

- starchlite white bean seeds e.g. aaiu 3,000 (3,000 alpha amylase inhibiting unit) $500.0 \mathrm{mg}$

- glucomannan $1,000.0 \mathrm{mg}$

- excipients, sweeteners, flavoring or similar tropical

The composition of the product (containing casein) was:

- Casein of milk concentrated $80 \% 10,000.0 \mathrm{mg}$

- $\quad$ starchlite white bean seeds e.g. aaiu 3,000 (3,000 alpha amylase inhibiting unit) $500.0 \mathrm{mg}$

- glucomannan $1,000.0 \mathrm{mg}$

- excipients, sweeteners, flavoring or similar tropical

\section{Statistical evaluation}

Five healthy subjects were enrolled in this crossover study.

All data were tabulated and subjected to appropriate statistical analysis by the biostatistics SPSS package.

Effectiveness and tolerability regarding the subjects who completed the study (drop-outs were replaced) were measured. Student's $t$ tests were used for parametric data and the Wilcoxon's test was relied on for non-parametric tests.

The non-parametric Friedman test was applied to evaluate the differences in satiation feeling (Haber's score). If significant differences were identified, all the possible pairwise comparisons were investigated with non-parametric
Wilcoxon's test for paired data, adjusting the reference, the $P$ value (0.05), according to Bonferroni's method.

The efficacy on the feeling of satiety was assessed by the net change from the baseline at the end of follow-up. Unpaired $t$ test (with Satterthwaite's correction for degrees of freedom) or the analogous non-parametric WilcoxonMann-Whitney's test (MW) was applied. A value of $P<0.05$ was considered significant (two-side).

\section{Results}

Analysis of the data showed that the WP administration induced a significant decrease in appetite after $90 \mathrm{~min}$ $(P<0.05)$ compared to casein (Table 1$)$.

Plasma gut hormone concentration increased significantly only for GLP-1 $(P<0.05)$ after $90 \mathrm{~min}$ in WP group, while after $180 \min (P<0.05)$ in the casein group (Tables 1, 2). There is a significant correlation between GLP-1 and decrease in appetite in WP $(R=-0.93)$. CCK concentration tends to increase after 90 min even though it does not attain statistical significance $(P=0.091)$.

\section{Discussion and conclusions}

Since, glucomannan cannot affect gut hormone response [9-13] and similarly, phaseolamin does not affect gut hormone-mediated appetite modulation because it blocks amylase in the digestion of complex carbohydrates (starch), the discussion will focus on the different protein compositions of the supplement [14-17].

Table 1 Appetite and enterohormonal profile following whey proteins

\begin{tabular}{lcllcr}
\hline Time (min.) & $0^{\prime}$ & $15^{\prime}$ & $30^{\prime}$ & $90^{\prime}$ & $180^{\prime}$ \\
\hline Appetite & $15.0 \pm 4.3$ & $12.6 \pm 4.3$ & $12.6 \pm 4.2$ & $12.2 \pm 4.0^{*}$ & $13.2 \pm 4.8$ \\
GLP-1 pmol/1 & $6.16 \pm 1.78$ & $6.80 \pm 1.61$ & $6.94 \pm 1.7$ & $7.11 \pm 1.08^{* *}$ & $6.77 \pm 2.09$ \\
CCK ng/mL & $1.1 \pm 0.1$ & $1.17 \pm 0.18$ & $1.17 \pm 0.17$ & $1.3 \pm 0.25$ & $1.16 \pm 0.16$ \\
PYY $\mathrm{pg} / \mathrm{mL}$ & $19.7 \pm 0.3$ & $19.4 \pm 0.5$ & $19.6 \pm 0.3$ & $19.7 \pm 0.5$ & $19.7 \pm 0.4$ \\
\hline
\end{tabular}

$C C K$ NS, $P Y Y$ NS

* Appetite: T0 vs. T90 $P=0.0446$

** GLP-1: T0 vs. T90 $P=0.0166$

Table 2 Appetite and enterohormonal profile following casein

Appetite NS, CCK NS, PYY NS

* GLP-1: T0 vs. T180

$P=0.0129$

\begin{tabular}{lcrrrr}
\hline Time (min.) & \multicolumn{1}{c}{$0^{\prime}$} & \multicolumn{1}{c}{$15^{\prime}$} & \multicolumn{1}{c}{$30^{\prime}$} & \multicolumn{1}{c}{$90^{\prime}$} & \multicolumn{1}{c}{$180^{\prime}$} \\
\hline Appetite & $11.4 \pm 7.8$ & $9.6 \pm 6.4$ & $7.7 \pm 4.7$ & $9.4 \pm 5.5$ & $11.8 \pm 6.8$ \\
GLP-1 & $7.0 \pm 1.1^{*}$ & $7.1 \pm 1.2$ & $6.74 \pm 1.1$ & $7.2 \pm 1.2$ & $7.2 \pm 1.2^{*}$ \\
CCK & $1.4 \pm 0.1$ & $1.3 \pm 0.2$ & $1.3 \pm 0.1$ & $1.4 \pm 0.1$ & $1.4 \pm 0.1$ \\
PYY pg/mL & $19.7 \pm 0.3$ & $19.5 \pm 0.3$ & $19.7 \pm 0.4$ & $19.8 \pm 0.5$ & $19.9 \pm 0.6$ \\
\hline
\end{tabular}


It is well known that, compared to a standard diet, a high-protein diet increases satiety, postprandial thermogenesis (by decreasing energy efficiency in futile cycles), basal metabolism, protein balance, and fat oxidation [17]. In addition, high biological value proteins have a greater effect on energy expenditure than the others. Finally, a protein-rich diet seems to have a positive effect on bone mineralization and to cause a reduction of fractures due to osteoporosis [18]. Physiologically, a high-protein diet produces a prolonged feeling of satiety by stimulating the secretion of anorectic hormones [19].

Despite these interesting premises, a highly hyper protein diet ( $>2 \mathrm{~g} / \mathrm{kg} /$ day) can cause nitrogen overload on the kidney due to sulfur amino acids, therefore, caution should be taken in considering this approach in patients with or at risk of renal disease and those with metabolic syndrome, [1]. This is why in recent years, more attention has been focused on evaluating the anorectic components of proteins to check the difference in their compositions so that they may be used in a more rational and modular manner.

Veldhorst et al. [20] noted that in a diet where $10 \%$ of energy was provided by proteins, WP showed a greater satiating effect than caseins and soy proteins. When dietary protein provided $25 \%$ of energy, differences in satiety induced by the three different types of proteins were no longer observed, although the WP induced a greater hormonal stimulation. The authors concluded that the differences observed were the result of the different amounts of amino acids, some of which were present in greater concentrations, beyond the threshold for activation of anorectic gut hormone secretion.

Recent studies in animals and humans have shown that WP have anorexigenic properties that may be a potential weapon for overweight management [20-23]. In particular, studies by Sukkar and others [21, 22] have shown that WPs are able to reduce food intake and consequently gain weight both in Wistar and in obesity-prone Zucker rats.

Whey proteins may reduce caloric intake as a result of various physiological mechanisms. CMP, which is the precursor protein of GMP, a bioproduct of rennin (chymosin) and a component of whey (1.2-1.5 g/L) may have anorectic activity. Over 20 years ago, it was shown that GMP can affect gastrointestinal function through the inhibition of gastric secretion [24], and that this action could be mediated by peptide hormones, such as CCK $[25,26]$, a potent activator of satiety signals. The CCK-like activity of GMP was confirmed by subsequent studies [27, 28].

Studies by Veldhorst et al. [29] confirmed that, being a WP fraction, GMP reduces energy intake because of its greater content in amino acids: serine, threonine, alanine, isoleucine, and $\alpha$-aminobutyric acid, regardless of the remaining WP components. Whey proteins were found to determine a maximum satiety response in that once a certain anorectic hormone concentration is reached, the effect on satiety plateaus irrespective of the progressive increase in anorectic hormones due to additional whey protein intake [29].

The control of satiety by WP is also determined by a second mechanism related to their physical and chemical properties. These properties bring about different digestion and absorption modalities resulting in differing degrees of amino-acid release, with circulating postprandial AA levels acting as one of the main factors that influence satiety.

Proteins may be "fast" or "slow" depending on their different digestion and absorption times and on their contribution to protein synthesis and postprandial plasma AA concentrations [30]. After ingestion, WP rapidly pass through the stomach and reach the jejunum as intact proteins. By contrast, casein undergoes substantial digestion in the stomach due to the strongly acid environment and coagulates forming lumps, passing more slowly through the small intestine. In the small intestine, whey protein is hydrolyzed more slowly than the other proteins, and digested and absorbed within a wider tract [31].

Based on the plasma amino-acid concentrations observed after an oral load, whey digestion and absorption of its amino acids were found to be clearly more rapid than casein. Similarly, mice and rats fed with whey reduce their food intake $30 \mathrm{~min}$ after administration than when fed with casein [21, 32].

Whey proteins are considered to be the highest quality proteins with the best biological value [33]. The protein efficiency ratio (PER), which reflects the weight gain in laboratory animals per gram of protein taken after 4 weeks, is very high (3.2) and greater than casein (2.6). This feature may be one of the factors that determine their satiating power since, compared to other proteins, whey proteins contain a higher concentration of branched-chain amino acids, especially L-leucine. Sweet and dry wheys contain 10.3 and $10.5 \%$ leucine, respectively [34]. Leucine acts on an mTOR-dependent kinase that is non-insulin dependent, promotes anabolism of muscle tissue, maintains stable glucose levels, and lowers insulin during energy restriction [35]. Leucine crosses the blood-brain barrier more rapidly than other amino acids [36], and its important role in hypothalamic regulation of food intake has been demonstrated in the recent studies [36].

Direct intracerebroventricular injection of amino-acid mixtures (RPMI 1640) and leucine alone (1 g) inhibits food intake for $24 \mathrm{~h}$, indicating that an increase in brain aminoacid concentrations is sufficient to suppress food intake. This effect is related to increased mRNA Agrp (Agoutirelated protein) levels in hypothalamic GT1-7 cells exposed to low-amino-acid concentrations for $16 \mathrm{~h}$, and is attenuated when leucine is removed from the cell culture 
[37]. It may be mediated by metabolic-sensing neurons [38, 39] via an mTOR-dependent mechanism [40], in which an increase in the brain amino-acid concentration leads to appetite inhibition [41].

Increasing evidence has shown that the effect of whey proteins on satiety and food intake is mediated by the effect of satiety-inducing hormone release [7, 42].

Cholecystokinin is known as a satiety hormone [7], in rats, CCK and its receptor subtype $\mathrm{A}$ are involved in the suppression of food intake induced by proteins [43, 44]. In humans, proteins and fats in the diet are the main stimulators of CCK secretion [45], and digestion of proteins is necessary for the release of CCK [46]. Milk proteins increase CCK plasma concentration, with an initial peak after 15-20 min, following, which there is a fall and a subsequent increase after about $90 \mathrm{~min}$ [23, 47].

Whey increased CCK concentration to a greater extent than did casein in a study by Hall [23] but not in one by Bowen [47]. This could be due to differences in the GMP content of the wheys used in the investigations.

Glucagon-like peptide-1 also appears to play a role in protein-induced satiety [47]. Both carbohydrates and fats are potent stimulators of GLP-1 [48], but milk proteins stimulate the release of GLP-1 regardless of the presence or absence of carbohydrates and fats [48].

Whey appears to have a more potent action and its secretagogue effect can be increased in the presence of other micronutrients.

A high-protein breakfast (58\% of total energy), consisting mainly of whey protein-enriched dietetic products, increases GLP-1 concentrations after $3 \mathrm{~h}$ compared to a high-carbohydrate breakfast with yoghurt (mainly casein) [49].

In human studies, a whey protein load (50 g) administered with $200 \mathrm{kcal}$ from fats and carbohydrates caused greater GLP-1 plasma concentrations than casein, again after $3 \mathrm{~h}$ [23].

Evidence of the indirect role of GLP-1 on milk proteininduced satiety was provided by studies on rats showing that exendin-4 (Ex-4), a GLP-1 receptor agonist, interacts with milk proteins in suppressing food intake $[50,51]$. This effect was observed both when the proteins were administered intact, partially hydrolyzed or in the form of free amino acids [51].

The glucose-dependent insulinotropic polypeptide, GIP, is released by $\mathrm{K}$ cells in the duodenum after food intake, and may have an important role in the development of obesity, since GIP receptor knockout mice were observed to be resistant to obesity even if fed a high-fat diet [42]. Recent studies have shown that a whey-containing beverage significantly increased GIP response (to $80 \%$ ) in healthy subjects, while mixtures of branched-chain amino acids did not have the same effect [52].
It is possible that bioactive peptides present in whey or formed during digestion are the main stimulators of GIP secretion [52]. Branched-chain amino-acid mixtures do not stimulate gut hormone (GIP and GLP-1) response, whereas whey protein drinks produce an increased response, suggesting that the action of whey proteins is not simply related to the amino-acid content but it is also due to the action of peptics [52].

The peptide YY is a gut hormone secreted by intestinal $\mathrm{L}$ cells and is present throughout the intestinal tract, with a higher concentration in the distal ileum [42]. PYY is secreted postprandially proportional to caloric intake and depends on macronutrient composition [53]. PYY plasma concentration increases after the intragastric administration of whey proteins or whey peptides hydrolysates in healthy subjects, and it is not related to the degree of protein fractionation [52]. No comparisons between the effect of whey and that of other proteins have been reported.

Ghrelin is a digestive orexigenic hormone [42] released into the circulation by the stomach; its concentrations generally reach a peak before meals, while its action is suppressed by food intake [54]. Like other digestive hormones, ghrelin plasma response depends on the macronutrient composition of the meal.

All three classes of macronutrients can suppress plasma ghrelin, but with different levels of efficiency [54].

Loads of milk protein, casein, whey or GMP in rats all produced a similar reduction of ghrelin plasma concentrations after 30 min compared to placebo (water alone) [32].

In humans, whey proteins and calcium caseinate suppress ghrelin concentrations similarly to lactose and more than glucose after $3 \mathrm{~h}$. This effect was correlated with a further reduction in subsequent energy intake [48].

Milk proteins and particularly the whey protein fraction have bioactive properties (hormones, growth factors, cytokines, antioxidants and stimulation of protein synthesis), which determine physiological regulations. Whey proteins also have an antioxidant effect that could be useful in controlling the oxidative stress occurring in the metabolic syndrome. They increase glutathione (GSH) synthesis and have been shown to boost immunity by increasing lymphocyte and splenic GSH synthesis [21, 55-64].

Recently, Pall et al. [65] have shown that total and LDL cholesterol reduced significantly after a 12-week treatment with whey proteins versus casein, in 70 obese human subjects $\left(\mathrm{BMI}=1.3 \pm 0.8 \mathrm{~kg} / \mathrm{m}^{2}\right)$

In sum, analysis of the findings reported revealed that a whey protein load induced a significant decrease in eating desire after $90 \mathrm{~min}(P<0.05)$, compared to casein. As for the gut hormone plasma concentrations, only GLP-1 increased significantly $(P<0.05) 90 \mathrm{~min}$ after whey protein administration and 180 min after casein administration $(P<0.05)$ and there was a significant correlation between 
GLP-1 and decreased eating desire $(R=-0.93)$. CCK concentrations also tended to increase after $90 \mathrm{~min}$, but this is not statistically significant $(P=0.091)$ for whey proteins. PYY displayed no significant changes after either whey protein or casein loads.

These results may be due to:

1. the small number of cases studied

2. the small amount of proteins used.

In fact, other experiments have actually shown a significant increase in CCK and PYY after administration of 20-58 g of whey proteins.

With regard to PYY, the findings reported are not consistent with the data described in the literature for the same reasons itemized for CCK. Given the small amount of whey proteins used, the proteins may not have reached the site where there is a greater PYY secretion as they are absorbed in the duodenum and jejunum, while the PYYsecreting cells are mainly localized in the distal ileum [66].

In conclusion, this study suggests that a mixture of whey proteins and glucomannan reduces eating desire and that this effect is related both to the changes in gut hormone levels (GLP-1) despite the low protein content (10 g), and to the presence of glucomannan that forms a "net" after gelling in the acid milieu of the stomach.

It is interesting to note that the result was achieved despite the low protein content (10 g), which is compatible with a clinical use of product. Elsewhere in the literature mixtures containing $50 \mathrm{~g}$ of whey proteins had been used [10].

In light of these results, we suggest that dietary supplementation with whey proteins might be employed as a treatment for appetite control. Whey proteins present the added value of being a source of branched-chain amino acids and leucine that are particularly appropriated for lean body mass maintenance in the course of low-calorie diets.

Future studies on larger populations are called for further investigations to analyze the effects both on appetite and hormones (CCK, GLP-1, PYY 1-36), and varying the amounts of whey proteins versus caseins.

Acknowledgments The study was sponsored by Inpha 2000. Inpha $2000 \mathrm{srl}$ provided protein powder, but was not involved in protocol development, data collection, data-analysis and interpretation, manuscript writing or in the decision to submit the manuscript for publication.

\section{Conflict of interest None.}

Open Access This article is distributed under the terms of the Creative Commons Attribution License which permits any use, distribution, and reproduction in any medium, provided the original author(s) and the source are credited.

\section{References}

1. Anderson GH, Tecimer SN, Shah D, Zafar TA (2004) Protein source, quantity, and time of consumption determine the effect of proteins on short-term food intake in young men. J Nutr 134:3011-3015

2. Stan E, Chernikov MP (1979) Physiological activity of kappacasein glycomacropeptide. Vopr Med Khim 25:348-352

3. Aleinik SI, Stan E, Chernikov MP (1984) Glycopeptide obtained from k-casein and its effect on protein assimilation. Vopr Pitan 2:47-50

4. Stan EI, Ekimovskii AP, Aleinik SI, Zhuravlev BV (1988) Heterogeneity and physiological activity of bovine k-casein proteolysis products. Vopr Pitan 1:39-43

5. Beucher S, Levenez F, Yvon M, Corring T (1994) Effects of gastric digestive products from casein on CCK release by intestinal cells in rat. J Nutr Biochem 5:578-584

6. Pedersen NL, Nagain-Domaine C, Mahe S, Chariot J, Roze C, Tome D (2000) Caseinomacropeptide specifically stimulates exocrine pancreatic secretion in the anesthetized rat. Peptides 21:1527-1535

7. Samra RA, Wolever TM, Anderson GH (2007) Enhanced food intake regulatory responses after a glucose drink in hyperinsulinemic men. Int J Obes (Lond) 31:1222-1231

8. Haber GB, Heaton KW, Murphy D, Burroughs LF (1977) Depletion and disruption of dietary fibre. Effects on satiety, plasmaglucose and serum insulin. Lancet 2:679-682

9. Chearskul S et al (2008) Immediate and long-term effects of glucomannan on total ghrelin and leptin in type 2 diabetes mellitus. Diabetes Res Clin Pract 83:e40-e42

10. Vita PM et al (1992) Chronic use of glucomannan in the dietary treatment of severe obesity. Minerva Med 83(3):135-139

11. Birketvedt GS et al (2004) Experiences with three different fiber supplements in weight reduction. Med Sci Monit 11(1):PI5-PI8

12. Kraemer WJ et al (2007) Effect of adding exercise to a diet containing glucomannan. Metabolism 56(8):1149-1158

13. Sala-Salvado J et al (2008) Effect of two doses of a mixture of soluble fibres on body weight and metabolic variables in overweight or obese patients: a randomised trial. Br J Nutr 99(6): 1380-1387

14. Gibbs BF, Alli I (1998) Characterization of a purified $\alpha$-amylase inhibitor from white kidney beans (Phaseolus vulgaris). Food Res Int 31(3):217-225

15. Obiro WC, Zhang T, Jiang B (2008) The nutraceutical role of the Phaseolus vulgaris alpha-amylase inhibitor. Br J Nutr 100(1): $1-12$

16. Udani J, Hardy M, Madsen DC (2004) Blocking carbohydrate absorption and weight loss: a clinical trial using Phase 2 brand proprietary fractionated white bean extract. Altern Med Rev 9(1):63-69

17. Lejeune MP, Westerterp KR, Adam TC, Luscombe-Marsh ND (2006) Westerterp-Plantenga MS Ghrelin and glucagon-like peptide 1 concentrations, 24-h satiety, and energy and substrate metabolism during a high-protein diet and measured in a respiration chamber. Am J Clin Nutr 83(1):89-94

18. Westerterp-Plantenga MS, Nieuwenhuizen A, Tomé D, Soenen S, Westerterp KR (2009) Dietary protein, weight loss, and weight maintenance. Annu Rev Nutr 29:21-41

19. Soenen S, Westerterp-Plantenga MS (2008) Proteins and satiety: implications for weight management. Curr Opin Clin Nutr Metab Care 11(6):747-751

20. Veldhorst MA, Nieuwenhuizen AG, Hochstenbach-Waelen A, van Vught AJ, Westerterp KR, Engelen MP, Brummer RJ, Deutz NE, Westerterp-Plantenga MS (2009) Dose-dependent satiating 
effect of whey relative to casein or soy. Physiol Behav 96(4-5): 675-682

21. Sukkar SG, Cella F, Patriarca S, Furfaro AL, Abate F, Ferrari C, Balbis E, Traverso N, Cotalasso D (2008) Whey protein, as exclusively nitrogen source, controls food intake and promotes glutathione antioxidant protection in Sprague-Dawley rats. Mediterr J Nutri Metab 1(2):109-116

22. Sukkar SG, Patriarca S, Furfaro AL, Balbis E, Traverso N, Abate F, Cottalasso D, Vaccaro A (2005) Whey protein inhibits food intake and tends to improve oxidative equilibrium in Zucker Rats. ADI Magazine 9(4):635-639

23. Hall WL, Millward DJ, Long SJ, Morgan LM (2003) Casein and whey exert different effects on plasma amino acid profiles, gastrointestinal hormone secretion and appetite. $\mathrm{Br} \mathrm{J}$ Nutr 89:239-248

24. Stan E, Chernikov MP (1979) Physiological activity of kappacasein glycomacropeptide. Vopr Med Khim 25:348-352

25. Aleinik SI, Stan E, Chernikov MP (1984) Glycopeptide obtained from k-casein and its effect on protein assimilation. Vopr Pitan 2:47-50

26. Stan EI, Ekimovskii AP, Aleinik SI, Zhuravlev BV (1988) Heterogeneity and physiological activity of bovine k-casein proteolysis products. Vopr Pitan 1:39-43

27. Beucher S, Levenez F, Yvon M, Corring T (1994) Effects of gastric digestive products from casein on CCK release by intestinal cells in rat. J Nutr Biochem 5:578-584

28. Pedersen NL, Nagain-Domaine C, Mahe S, Chariot J, Roze C, Tome D (2000) Caseinomacropeptide specifically stimulates exocrine pancreatic secretion in the anesthetized rat. Peptides 21:1527-1535

29. Veldhorst MA, Nieuwenhuizen AG, Hochstenbach-Waelen A, Westerterp KR, Engelen MP, Brummer RJ, Deutz NE, Westerterp-Plantenga MS (2009) Effects of complete whey-protein breakfasts versus whey without GMP-breakfasts on energy intake and satiety. Appetite 52(2):388-395

30. Boirie Y, Dangin M, Gachon P, Vasson MP, Maubois JL, Beaufrere B (1997) Slow and fast dietary proteins differently modulate postprandialprotein accretion. Proc Natl Acad Sci USA 94:14930-14935

31. Mahe S, Roos N, Benamouzig R, Davin L, Luengo C, Gagnon L, Gausserges N, Rautureau J, Tome D (1996) Gastrojejunal kinetics and the digestion of [15N]beta-lactoglobulin and casein in humans: the influence of the nature and quantity of the protein. Am J Clin Nutr 63:546-552

32. Peng X (2005) Milk proteins, glycomacropeptide, and regulation of short-term food intake in rats. Thesis (M.Sc.), University of Toronto

33. Hoffman JR, Falvo MJ (2004) Protein-which is best? J Sports Sci Med 3:118-130

34. Glass L, Hedrick T (1976) Nutritional composition of sweet- and acid- type dry wheys. 1. Major factors including amino acids. J Dairy Sci 60:185-189

35. Layman DK, Walker DA (2006) Potential importance of leucine in treatment of obesity and the metabolic syndrome. J Nutr 136:319S-323S

36. Yudkoff M, Daikhin Y, Nissim I, Horyn O, Luhovyy B, Lazarow A (2005) Brain amino acid requirements and toxicity: the example of leucine. J Nutr 135(6 Suppl):1531S-1538S

37. Morrison CD, Xi X, White CL, Ye J, Martin RJ (2007) Amino acids inhibit Agrp gene expression via an mTOR-dependent mechanism. Am J Physiol Endocrinol Metab 293:E165-E171

38. Seeley RJ, York DA (2005) Fuel sensing and the central nervous system (CNS): implications for the regulation of energy balance and the treatment for obesity. Obes Rev 6:259-265

39. Murphy KG, Bloom SR (2006) Gut hormones and the regulation of energy homeostasis. Nature 444:854-859
40. Levin BE (2006) Metabolic sensing neurons and the control of energy homeostasis. Physiol Behav 89:486-489

41. Anderson GH (1996) Hunger, appetite, and food intake. In: Ziegler EE, Filer LJ (eds) Present Knowledge in Nutrition, 7th edn. ILSI Press, Washington, DC, pp 13-18

42. Strader AD, Woods SC (2005) Gastrointestinal hormones and food intake. Gastroenterology 128:175-191

43. Figlewicz DP, Nadzan AM, Sipols AJ, Green PK, Liddle RA, Porte D Jr, Woods SC (1992) Intraventricular CCK-8 reduces single meal size in the baboon by interaction with type-A CCK receptors. Am J Physiol 263(4 Pt 2):R863-R867

44. Miesner J, Smith GP, Gibbs J, Tyrka A (1992) Intravenous infusion of CCKA-receptor antagonist increases food intake in rats. Am J Physiol 262(2 Pt 2):R216-R219

45. Liddle RA, Goldfine ID, Rosen MS, Taplitz RA, Williams JA (1985) Cholecystokinin bioactivity in human plasma. Molecular forms, responses to feeding, and relationship to gallbladder contraction. J Clin Invest 75:1144-1152

46. Liddle RA (1995) Regulation of cholecystokinin secretion by intraluminal releasing factors. Am J Physiol 269(3 Pt 1):G319-G327

47. Bowen J, Noakes M, Trenerry C, Clifton PM (2006) Energy intake, ghrelin, and cholecystokinin after different carbohydrate and protein preloads in overweight men. J Clin Endocrinol Metab 91:1477-1483

48. Brubaker PL, Anini Y (2003) Direct and indirect mechanisms regulating secretion of glucagon-like peptide-1 and glucagon-like peptide-2. Can J Physiol Pharmacol 81:1005-1012

49. Blom WA, Lluch A, Stafleu A, Vinoy S, Holst JJ, Schaafsma G, Hendriks HF (2006) Effect of a high-protein breakfast on the postprandial ghrelin response. Am J Clin Nutr 83:211-220

50. Aziz A, Anderson GH (2002) Exendin-4, a GLP-1 receptor agonist, modulates the effect of macronutrients on food intake by rats. J Nutr 132:990-995

51. Aziz A, Anderson GH (2003) Exendin-4, a GLP-1 receptor agonist, interacts with proteins and their products of digestion to suppress food intake in rats. J Nutr 133:2326-2330

52. Calbet JA, Holst JJ (2004) Gastric emptying, gastric secretion and enterogastrone response after administration of milk proteins or their peptide hydrolysates in humans. Eur J Nutr 43:127-139

53. Cummings DE, Overduin J (2007) Gastrointestinal regulation of food intake. J Clin Invest 117:13-23

54. Badman MK, Flier JS (2005) The gut and energy balance: visceral allies in the obesity wars. Science 307:1909-1914

55. Noelle RJ, Lawrence DA (1981) Determination of glutathione in lymphocytes and possible association of redox state and proliferative capacity of lymphocytes. Biochem J 198:571-579

56. Fidelus RK, Tsan MF (1987) Glutathione and lymphocyte activation: a function of aging and auto-immune disease. Immunology 61:503-508

57. Bounous G, Batist G, Gold P (1989) Immunoenhancing property of dietary whey protein in mice: role of glutathione. Clin Invest Med 12:54-61

58. Parker NT, Goodrum KJ (1990) A comparison of casein, lactalbumin, and soy protein, effect on the immune response to a T-dependent antigen. Nutr Res 10:781-792

59. Wong CW, Watson DL (1995) Immunomodulatory effects of dietary whey proteins in mice. J Dairy Res 62:350-368

60. Sukkar SG, Bounous G (2004) The role of whey protein in antioxidant defence. Riv Ital Nutr Parent Enter 22(4):193-200

61. Badaloo A, Reid M, Forrester T, Heird WC, Jahoor F (2002) Cysteine supplementation improves the erythrocyte glutathione synthesis rate in children with severe edematous malnutrition. Am J Clin Nutr 76(3):646-652

62. Droge W (1999) Cysteine and glutathione in catabolic conditions and immunological dysfunction. Curr Opin Clin Nutr Metab Care 2(3):227-233 
63. Bounous G, Batist G, Gold P (1989) Immunoenhancing property of dietary whey protein in mice: role of glutathione. Clin Invest Med 12:154-161

64. Bounous G, Kongshavn PA (1989) Influence of protein type in nutritionally adeguate diets on the development of immunity. In: Friedman M (ed) Absorption and utilization of amino acids. CRc Press, Boca Raton, pp 219-233
65. Pal Sebely, Ellis Vanessa, Dhaliwal Satvinder (2010) Effects of whey protein isolate on body composition, lipids, insulin and glucose in overweight and obese individuals. $\mathrm{Br} \mathrm{J}$ Nutr 104:716-723

66. Calbet JA, Holst JJ Gastric emptying, gastric secretion and enterogastrone response after administration of milk proteins or their peptide hydrolysates in humans. Eur J Nutr 43(3):127-139 